\title{
Survey of Attitudes, Knowledge, and Barriers to Evidence-Based Practice Among Thai Physical Therapists
}

\author{
Mantana Vongsirinavarat \\ Mahidol University, mantana.von@mahidol.edu \\ Witaya Mathiyakom \\ California State University, witaya.mathiyakom@csun.edu \\ Warin Krityakiarana \\ Mahidol University, warin.kri@mahidol.edu \\ Ninwisan Hengsomboon \\ Mahidol University, ninwisan.sku@mahidol.edu \\ Ratchanok Kraiwong \\ MahidolUniversity, ratchanon.tha@mahidol.edu
}

Follow this and additional works at: https://nsuworks.nova.edu/ijahsp

Part of the Educational Assessment, Evaluation, and Research Commons, and the Medicine and Health Sciences Commons

\section{Recommended Citation}

Vongsirinavarat M, Mathiyakom W, Krityakiarana W, Hengsomboon N, Kraiwong R. Survey of Attitudes, Knowledge, and Barriers to Evidence-Based Practice Among Thai Physical Therapists. The Internet Journal of Allied Health Sciences and Practice. 2020 Jan 01;18(4), Article 1.

This Manuscript is brought to you for free and open access by the College of Health Care Sciences at NSUWorks. It has been accepted for inclusion in Internet Journal of Allied Health Sciences and Practice by an authorized editor of NSUWorks. For more information, please contact nsuworks@nova.edu. 


\title{
Survey of Attitudes, Knowledge, and Barriers to Evidence-Based Practice Among Thai Physical Therapists
}

\begin{abstract}
Purpose: Healthcare professionals are encouraged to use evidence-based practice (EBP) to improve the quality of care and the patient's quality of life. Knowledge and skill set specific to EBP, critical resources such as time and accessibility to databases, and clinician's attitude toward EBP are needed for successful implementation of EBP. However, little is currently known about these factors among Thai Physical Therapists (PTs). This study aimed to explore the patterns of attitudes, perceived knowledge, and barriers toward EBP in Thai PTs. Method: An online questionnaire was used to obtain information regarding attitudes, knowledge, and barriers from Thai PTs. Descriptive statistics were used to describe the responses. Multiple logistic regression was used to determine the association between personal and work characteristics and the responses related to attitude, knowledge, and barriers. Results: A total of 719 Thai PTs responded to the questionnaire. Based on this sample, Thai PTs had positive attitudes and perceived themselves as having sufficient background EBP education and skills. They were confident in performing a literature search, critically appraisal, and applying research in their practice. However, the frequencies of searching and reading of literature were relatively low. Less than half of respondents understood terms related to EBP asked in the survey instrument. The barriers to EBP were insufficient time and limited research and statistical skills. PTs who were younger and having higher education were more likely to have better attitudes and knowledge. Conclusions: Despite the positive attitude and perceived knowledge of EBP, time allocation, formal training of EBP skills during academic preparation, and continuing education are required to overcome the barriers toward EBP. The discrepancy between the perception and practice of EBP observed calls for further investigation of actual skills and the barriers to the implementation of EBP.
\end{abstract}

\section{Author Bio(s)}

Mantana Vongsirinavarat, PhD. (Texas' Women University), DPT (University of Montana). Mantana is an Assistant Professor in the Faculty of Physical Therapy, Mahidol University.

Witaya Mathiyakom, PhD. (University of Southern California). Witaya is a Professor in the Department of Physical Therapy, California State University, Northridge and Adjunct Professor Department of Biological Sciences University of Southern California.

Warin Krityakiarana, Ph.D. (Mahidol University). Warin is an Assistant Professor in the Faculty of Physical Therapy, Mahidol University.

Ninwisan Hengsomboon, PhD. (Chulalongkorn University). Ninwisan is a lecturer in the Faculty of Physical Therapy, Mahidol University.

Ratchanok Kraiwong, Ph.D. (Mahidol University). Ratchanok is a lecturer in the Faculty of Physical Therapy, Mahidol University.

\section{Acknowledgements}

This study is supported in part by the Physical Therapy Association of Thailand. The authors also would like to acknowledge the presidents of the Physical Therapy Council and the Physical Therapy Association of Thailand for their supports of information of registered practitioners and networks of physical therapists. 


\title{
IJAHSP \\ The Internet Journal of Allied Health Sciences and Practice
}

Dedicated to allied health professional practice and education

Vol. 18 No. 4 ISSN 1540-580X

\section{Survey of Attitudes, Knowledge, and Barriers to Evidence-Based Practice Among Thai Physical Therapists}

\author{
Mantana Vongsirinavarat ${ }^{1}$ \\ Witaya Mathiyakom² \\ Warin Krityakiarana ${ }^{1}$ \\ Ninwisan Hengsomboon ${ }^{1}$ \\ Ratchanok Kraiwong ${ }^{1}$ \\ 1. Mahidol University \\ 2. California State University \\ Thailand, United States
}

\begin{abstract}
Purpose: Healthcare professionals are encouraged to use evidence-based practice (EBP) to improve the quality of care and the patient's quality of life. Knowledge and skill set specific to EBP, critical resources such as time and accessibility to databases, and clinician's attitude toward EBP are needed for successful implementation of EBP. However, little is currently known about these factors among Thai Physical Therapists (PTs). This study aimed to explore the patterns of attitudes, perceived knowledge, and barriers toward EBP in Thai PTs. Method: An online questionnaire was used to obtain information regarding attitudes, knowledge, and barriers from Thai PTs. Descriptive statistics were used to describe the responses. Multiple logistic regression was used to determine the association between personal and work characteristics and the responses related to attitude, knowledge, and barriers. Results: A total of 719 Thai PTs responded to the questionnaire. Based on this sample, Thai PTs had positive attitudes and perceived themselves as having sufficient background EBP education and skills. They were confident in performing a literature search, critically appraisal, and applying research in their practice. However, the frequencies of searching and reading of literature were relatively low. Less than half of respondents understood terms related to EBP asked in the survey instrument. The barriers to EBP were insufficient time and limited research and statistical skills. PTs who were younger and having higher education were more likely to have better attitudes and knowledge. Conclusions: Despite the positive attitude and perceived knowledge of EBP, time allocation, formal training of EBP skills during academic preparation, and continuing education are required to overcome the barriers toward EBP. The discrepancy between the perception and practice of EBP observed calls for further investigation of actual skills and the barriers to the implementation of EBP.
\end{abstract}

Keywords: evidence-based practice; physical therapy; cross-sectional study; Thailand

(c) The Internet Journal of Allied Health Sciences and Practice, 2020 


\section{INTRODUCTION}

Evidence-based practice (EBP) has been growing in all healthcare practices, as it has shown to heighten the quality of care, reduce healthcare cost, and improve patient's quality of life. . $^{1-3}$ Successful implementation of EBP requires physical therapists (PTs) to incorporate the best available evidence with their clinical skills and patients' values and preferences., ${ }^{3,4}$ Physical Therapy (PT) professional organizations at both international and national levels encourage their members to use EBP in their practice. ${ }^{1}$ Knowledge and skill sets specific to EBP are important for successful implementation of EBP. ${ }^{2}$ Additionally, critical resources such as time and accessibility to databases must be available. Without these essential components, the implementation of EBP in clinical practice will be extremely limited.

Recent studies related to the implementation of EBP in PT practice demonstrated different levels of uses, attitudes, and barriers among PTs. 5,6 These disparities are attributable to the diverse educational levels, age of practitioners, and practice system. . $^{7-16}$ PTs with a higher level of education have relatively better attitudes toward EBP and were more likely to implement EBP in their clinical practice as compared to PTs with only entry-level education. 7,12,14 Younger PTs appear to have better knowledge and seem to adopt EBP more readily in their practice as compared to their counterparts.7,8,11,12,14,16 Barriers to EBP typically reported are the lack of time, research skills, and resources. $7,8,11-13,15-18$

In Thailand, physical therapy is a licensed health professional with a 4-year university entry-level education. Once licensed, Thai PTs are required to obtain a certain amount of continuing educational units to renew their licenses. Both academic preparation and continuing education allow Thai PTs to have direct access and autonomy of practice. Effectiveness of Thai PTs to make a clinical decision accurately relies heavily on their ability to use EBP in their practice. As a result, many PT programs in Thailand have integrated the EBP content into their entry-level curriculum in hope that licensed PTs will able to successfully implement EBP in their clinical settings.

Unfortunately, little is currently known about the perceived knowledge, attitudes, and barriers to the implementation of EBP among Thai PTs. This information is of paramount importance for improving and expanding the use of EBP among Thai PTs. Therefore, this study aimed to describe the patterns of attitudes, perceived knowledge, and barriers to EBP implementation among Thai PTs. The associations between personal characteristics, practice environments, and implementation of EBP, were also explored.

\section{METHOD}

\section{Subjects}

This study employed a cross-sectional survey design and was approved by the Mahidol University Central Institutional Review Board (MU-CIRB) protocol no.2017-147.2308. The target population was the licensed PTs who were currently practicing in Thailand. The potential participants were invited via an electronic mail sent to the members of various PT networks in Thailand, such as the networks of PT in government healthcare services and PT in academic institutes. Additionally, social media including Facebook and Line applications were used to inform PTs about the study.

\section{Instrument}

The questionnaire used in this study was adapted from the one originally used by Jette et al. ${ }^{12}$ In the original study, the authors assessed the content validity in ten experienced PTs. ${ }^{12}$ The test-retest reliability of each question in the original questionnaire was poor to excellent (ICC $=0.37-0.90$ ), with more than $50 \%$ of the items having ICCs greater than 0.07 . The dichotomous items had $68 \%$ to $93 \%$ agreements and the ranked items had $59 \%$ to $80 \%$ agreement. ${ }^{12}$ After getting permission from the first author of the original study, the questionnaire was translated into the Thai language by the first and third authors of this study. The questionnaire was translated back to English by the second author. The three authors edited and verified the backward translation to ensure that the meaning of each question was maintained. All main content of the questionnaire was unchanged, but questions related to educational level and practice were modified to reflect the current PT practice in Thailand. The questionnaire was tested in a pilot study of ten Thai PTs with different age groups and educational levels to ensure its intended meaning and readability. None of the items were changed after the pilot study. The questionnaire used in this study is presented in Appendix 1.

The final version of Thai questionnaire contained five themes, including 1) attitudes and concerns, 2) perceived knowledge and skills related to EBP, 3) access to and availability of information, 4) attention to the literature relevant to practice, and 5) perceived barriers to using evidence in practice. The responses of questions were either on a 5-point Likert scale ("Strongly Disagree" to "Strongly Agree") or other forced-choice-type questions. The online format of the questionnaire was created using a standard Google survey form. The link to the questionnaire was attached to the electronic mail sent to the participants and posted on the Thai PT group-specific Facebook and Line applications from October 2017 to March 2018. The response to the questionnaire was anonymous.

(c) The Internet Journal of Allied Health Sciences and Practice, 2020 


\section{Data Analysis}

At the closing of data collection, the results were exported and coded for data analysis (IBM SPSS for window version 19.0 (SPSS Inc, IBM®, Chicago, Illinois)). For questions with a positive meaning, the response of "Agree" and "Strongly Agree" indicated agreement, while the "Neutral," "Disagree" and "Strongly disagree" were coded as disagreement. In contrast, for questions with negative meaning, the response of "Strongly Disagree," "Disagree," and "Neutral" indicated the agreement. Descriptive statistics were used to describe the responses. Additionally, characteristics of Thai PTs provided by the Thai Physical Therapy Council were used to provide the context for generalization of the results.

Multiple logistic regression models were constructed to identify the factors contributing to the major items associated to the five major themes. Nine independent variables of personal and working characteristics including gender, age, years holding a license, education level, working hours per week, number of patients seen per day, number of PTs in workplace, area of the workplace, and being a clinical instructor $(\mathrm{Cl})$ were used as contributing factors. These variables were eligible for entry into a multiple logistic regression model if they were significantly associated with EBP themes based on Chi-square $(p<0.25) .{ }^{19}$ The estimated coefficients and their standard errors (SEs) were calculated using the maximum likelihood ratio. The backward stepwise method was used for variable selection. The calibration was assessed using the Hosmer-Lemeshow goodness-of-fit test. ${ }^{19,20}$ Discrimination was assessed using the area under the receiver operating characteristic (AUROC) to evaluate the overall predictive accuracy of the model. ${ }^{19-21}$ The models with $p<0.01$ and AUROC $>0.60$ were considered significant and reported for interpreting the influences of personal and working characteristics on the responses of each item. Odds ratios were presented to describe the likelihood of agreeing with the behaviors of each item given specific characteristic. Considering the most salient interpretation of results, one level of each variable was chosen as the reference group.

\section{RESULTS}

\section{Respondents}

Table 1 summarizes the demographic, education, and professional practice data of the 719 respondents $(4.1 \%$ of 15,086 registered PTs in Thailand) who were eligible and completed the questionnaire, and the available demographic data of Thai PTs provided by the Thai Physical Therapy Council. The majority of the respondents was female, aged 20-29 years, holding a license for 5-10 years, completed a bachelor's degree as the highest education level, graduated from a public university, and regularly participated in continuing education. The majority of respondents worked more than 40 hours per week, saw 5-10 patients a day, were not a Cl of PT students, had less than five PTs in the workplace, and worked in the urban area.

Table 1 Demographic, education and practice characteristics of participants $(n=719)$

\begin{tabular}{|l|c|c|}
\hline \multicolumn{1}{|c|}{ Characters } & Number (Percentage) & $\begin{array}{c}\text { Percentage of Thai PTs } \\
\text { (as of October 2018) }\end{array}$ \\
\hline Sex Female & $543(75.5)$ & 80.7 \\
Male & $176(24.5)$ & 19.3 \\
\hline Age group & $345(48.0)$ & 28.4 \\
20-29 years & $274(38.1)$ & 43.2 \\
$30-39$ years & $82(11.4)$ & 18.8 \\
$40-49$ years & $18(2.5)$ & 9.6 \\
$\geq 50$ years & $235(32.7)$ & \\
\hline Years holding license & $258(35.9)$ & \\
<5 years & $109(15.2)$ & \\
$5-10$ years & $116(16.1)$ & 94.6 \\
10-15 years & $515(71.6)$ & - \\
$>15$ years & $28(3.9)$ & 4.3 \\
\hline Education & $141(19.6)$ & 1.1 \\
Bachelor's degree & $32(4.5)$ & 82.6 \\
Postgraduate diploma & & 17.4 \\
Master's degree & $615(85.5)$ & - \\
Doctoral degree & $102(14.2)$ & \\
\hline University bachelor-graduated & & \\
Government & $600(83.4)$ & \\
Private & & \\
\hline Continuing education activity & & \\
Yes & & \\
\hline
\end{tabular}

(c) The Internet Journal of Allied Health Sciences and Practice, 2020 


\begin{tabular}{|l|c|c|}
\hline No & $117(16.3)$ & \\
\hline Working hours per week & $43(6.0)$ & \\
$<20$ hours & $62(8.6)$ & \\
$20-30$ hours & $264(36.7)$ & \\
$31-40$ hours & $349(48.5)$ & \\
$>40$ hours & $109(15.2)$ & \\
\hline Number of patients see per day & $291(40.5)$ & \\
$<5$ & $197(27.4)$ & \\
$5-10$ & $119(16.6)$ & \\
$11-15$ & $380(52.9)$ & \\
$>15$ & $158(22.0)$ & \\
\hline Number of PTs in the workplace & $58(8.1)$ & \\
$<5$ & $118(16.4)$ & \\
$5-10$ & $193(26.8)$ & \\
$11-15$ & $397(55.2)$ & \\
$>15$ & $127(17.7)$ & \\
\hline Area of workplace & $282(39.2)$ & \\
Rural & $435(60.5)$ & \\
Urban & \\
Suburban & \\
\hline Being Clinical instructor & & \\
Yes & & \\
No &
\end{tabular}

Table 2 summarizes the variables of personal and working characteristics having influences on the responses of each item. The odds ratios describing the likelihood of agreeing with the behaviors of each item given specific characteristics presented in Table 2 are presented in Appendix 2.

Table 2 Themes, their major items, and significant factors associated with the items based on multiple linear regression model

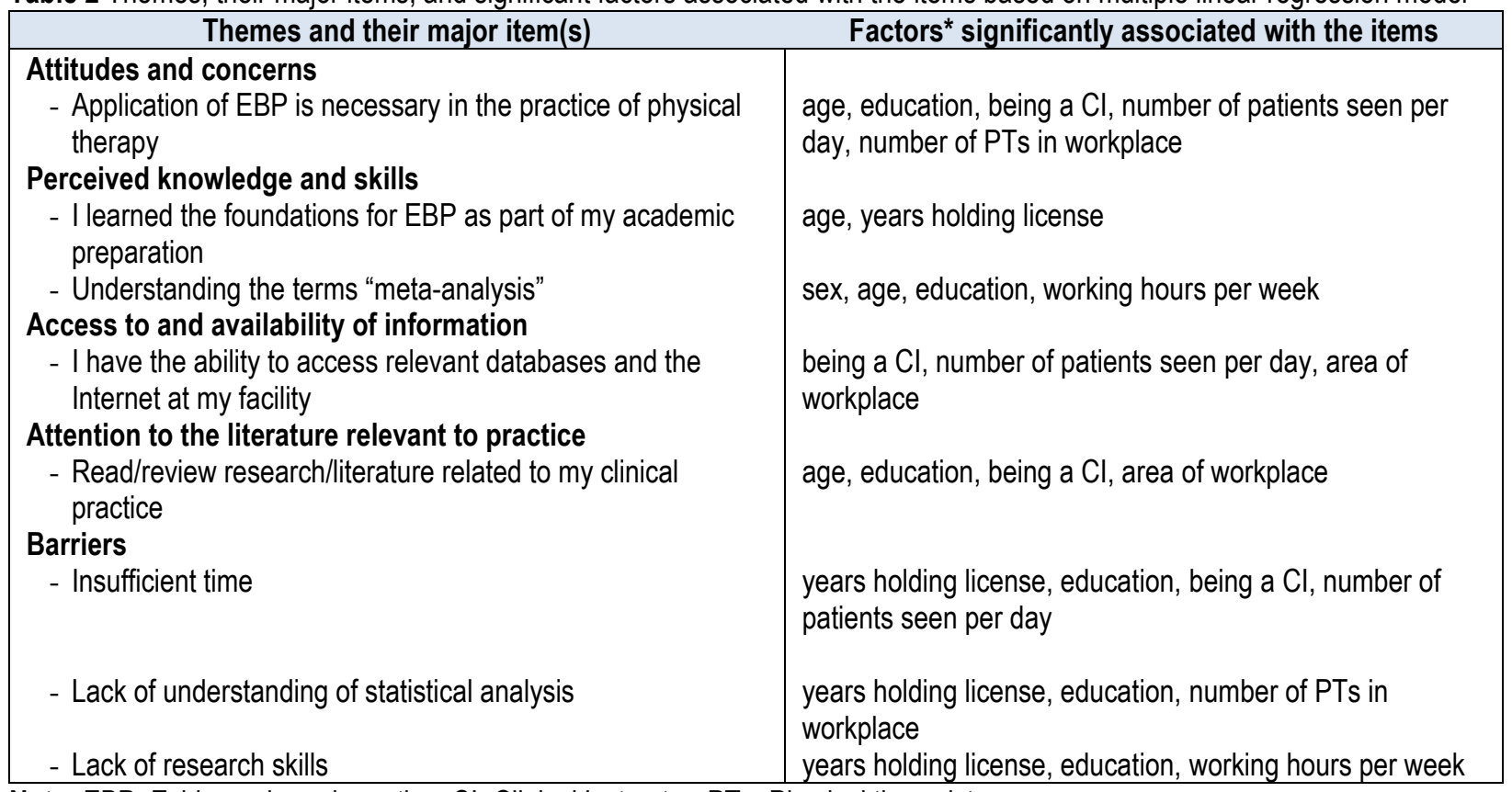

Note: EBP=Evidence-based practice; $\mathrm{Cl}=$ Clinical instructor; PTs=Physical therapists.

*The order of these factors was based on high to low odds ratio values. 


\section{Questionnaire Responses}

The questionnaire responses were analyzed and reported in five main themes 1) attitudes and concerns, 2) perceived knowledge and skills related to EBP, 3) access to and availability of information, 4) attention to the literature relevant to practice, and 5) perceived barriers to using evidence in practice.

\section{Attitudes and Concerns}

Figure 1 depicts the attitudes toward EBP and the concerns of using EBP. Thai PTs had positive attitudes toward EBP as indicated by the combined responses of "Agreed" and "Strongly Agreed" ranged from 79.3 to $92.9 \%$. The concerns about using EBP were identified by the combined responses of "Neutral", "Agreed", and "Strongly agreed" ranged from 38.6 to $74.8 \%$. PTs in younger age groups, with entry bachelor degree education, being a $\mathrm{Cl}$, seeing fewer patients per day, and having fewer numbers of PTs in their workplace were more likely to agree that the application of EBP was necessary for their practice as compared to their counterparts (Table 2, Appendix 2).

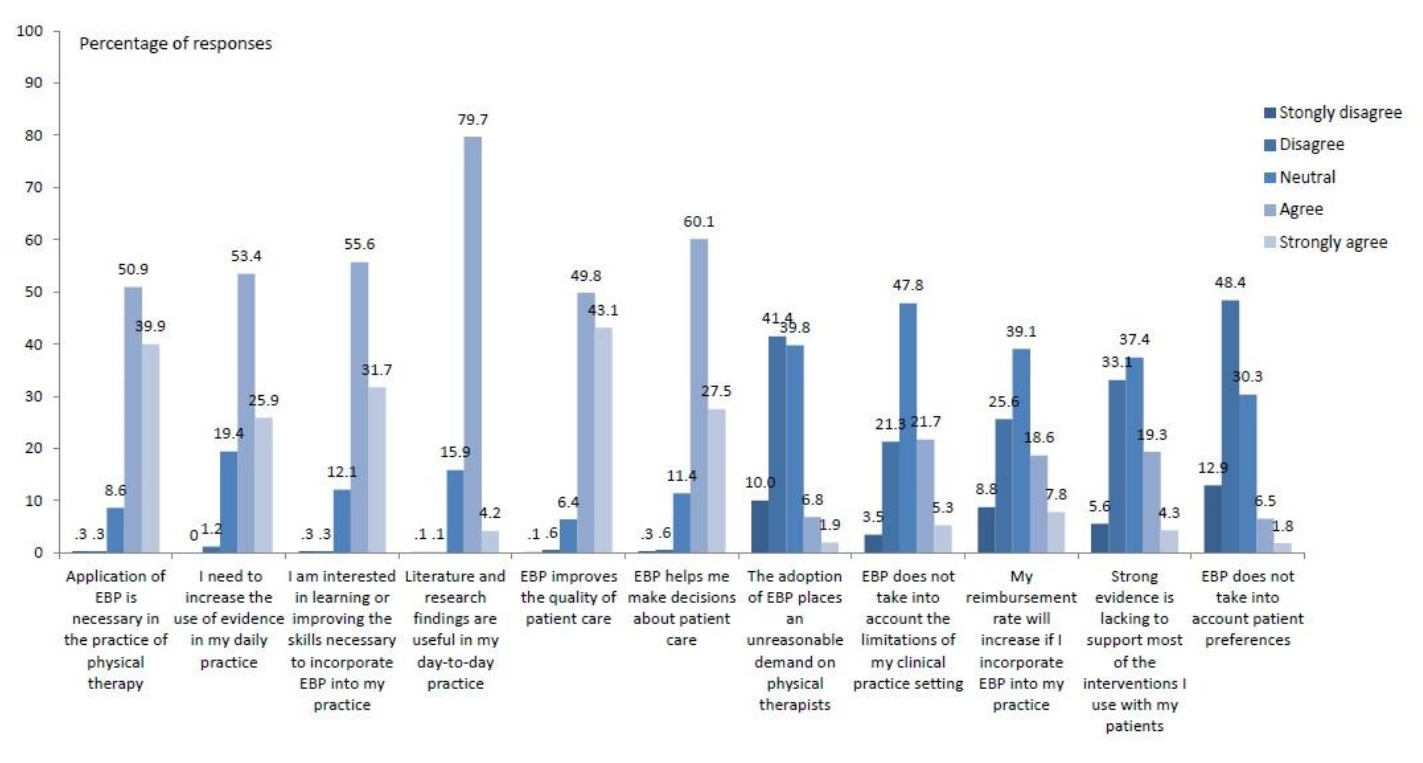

Figure 1. Responses of items related to the attitudes toward EBP and the concerns of using EBP

\section{Perceived Knowledge and Skills Related to EBP}

Figure 2 presents the perceived knowledge and skills related to assessing and interpreting the information from research. The majority of respondents (75-91\%) had positive experiences relevant to the background and knowledge of EBP. To further evaluate the knowledge specific to EBP, eight terms related to EBP were asked, and the responses are presented in Figure 3. Less than half (14.2-43.9\%) of respondents reported that they fully understood these terms. The respondents in younger age group and fewer years holding license learned the foundations for EBP as part of their academic preparation. PTs with higher education levels, working less hours per day, and worked with more PTs in the workplace were significantly more likely to report that they understood the terms related to EBP as compared to their counterparts (Table 2, Appendix 2) 


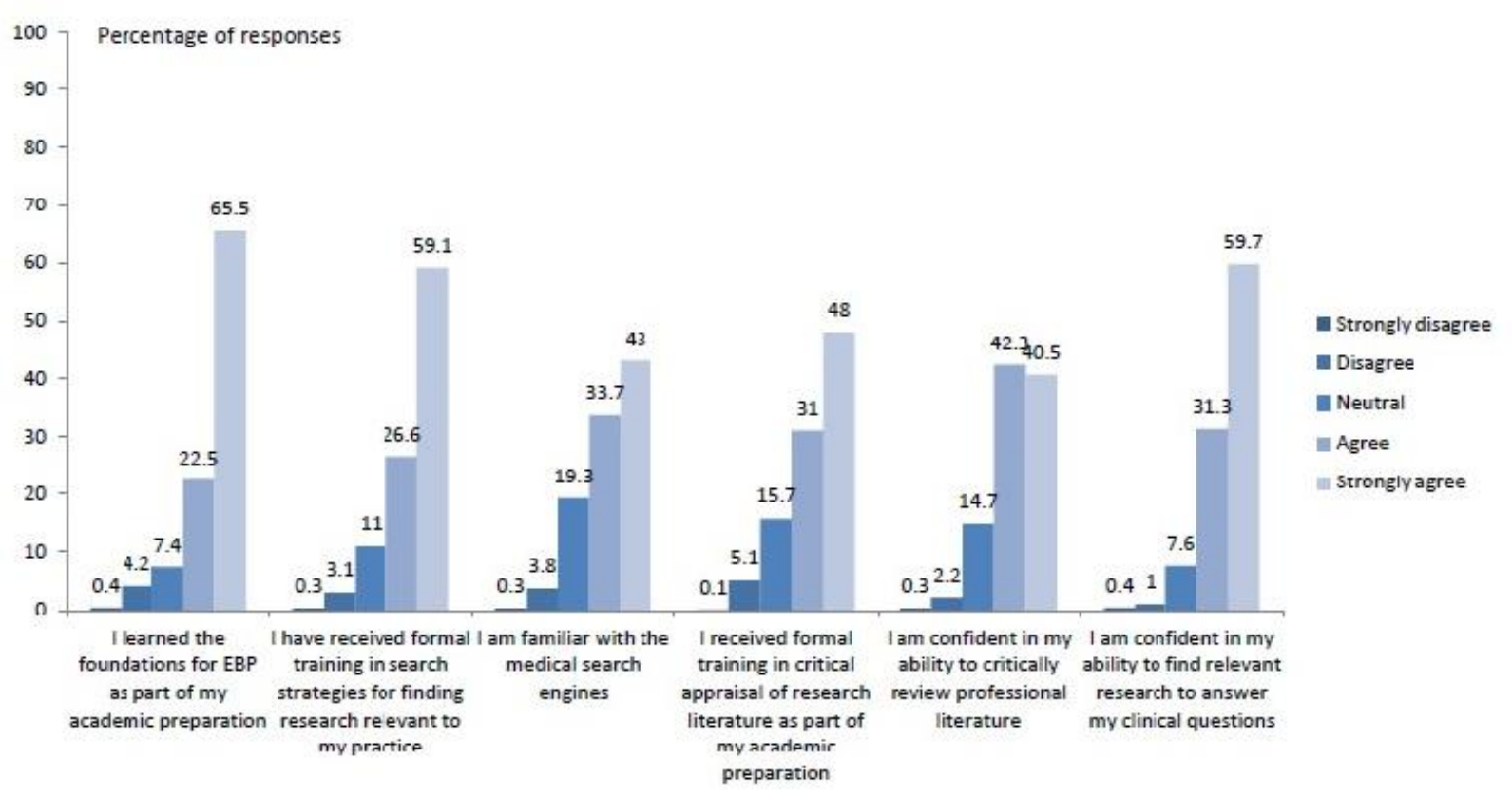

Figure 2. Responses of items regarding the perceived knowledge and skills related to EBP

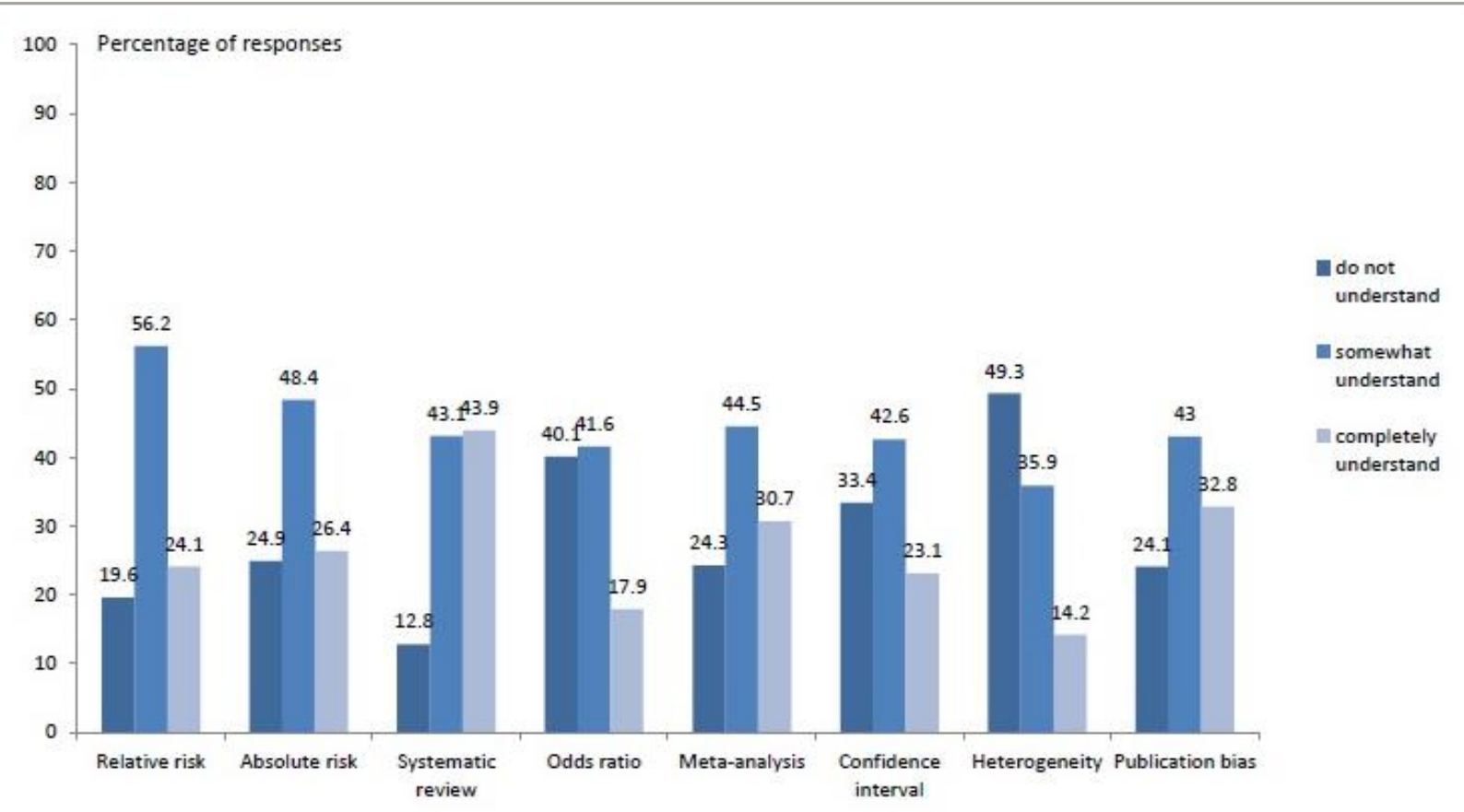

Figure 3. Responses of items regarding the understanding of terms related to EBP use

\section{Access to and Availability of Information}

Figure 4 shows the responses related to the access and the availability of information to promote EBP. The majority of respondents (73.3-83.4\%) were aware of and had internet access to obtain practice guidelines at home and workplace. Only $21.4 \%$ of respondents had access to the paper form of research articles. The participants who were not Cls, seeing more patients per day, and working in urban areas were more likely to be able to access relevant databases and internet in their facility (Table 2, Appendix 2). 


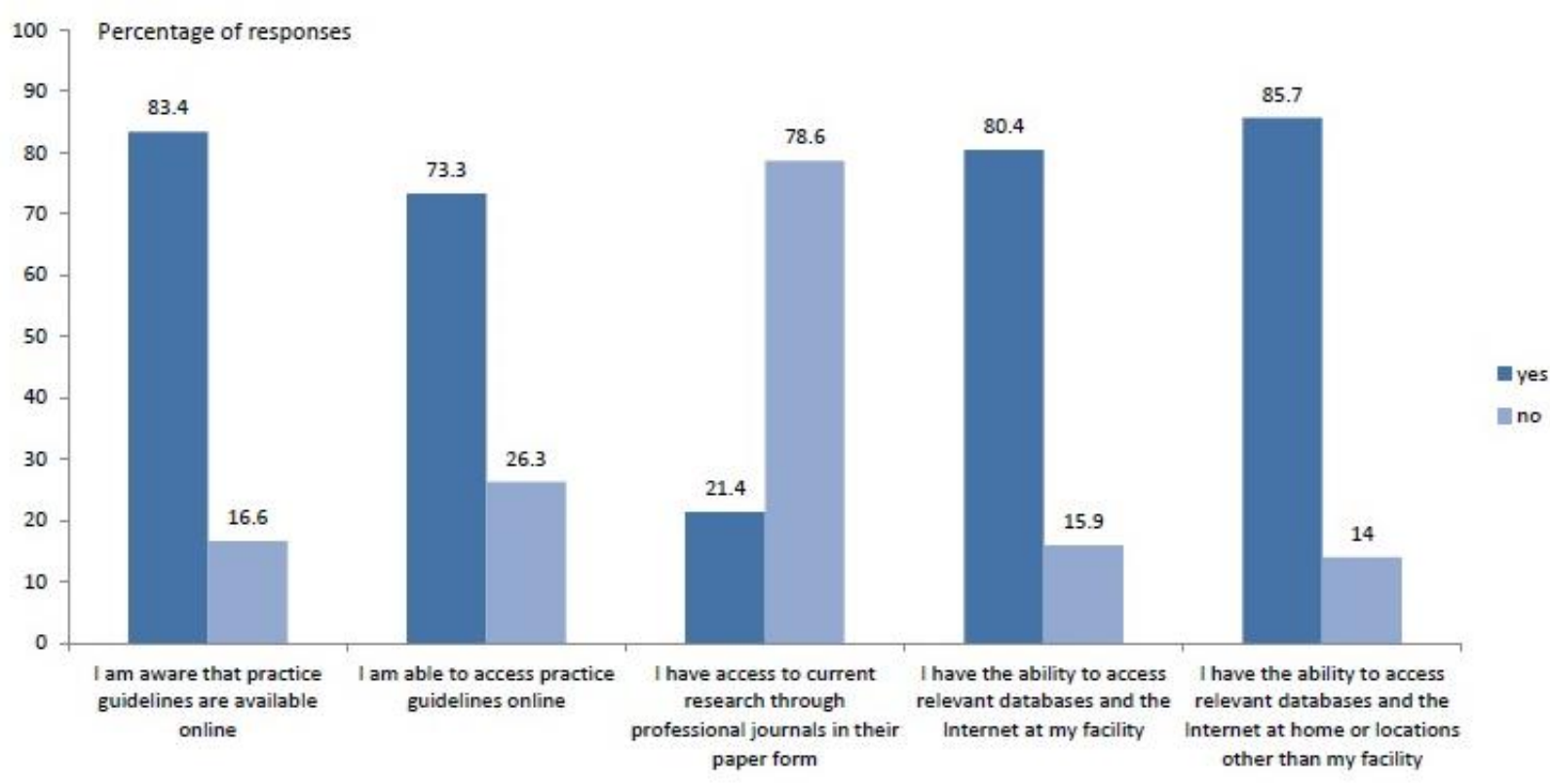

Figure 4. Responses of items related to the access to and availability of information to promote EBP

\section{Attention to the Literature Relevant to Practice}

In an average month, the majority of respondents read research literature related to their clinical practice $2-5$ times $(45 \%)$ or one time or less (38\%). Most of them used professional literature and research findings in the process of clinical decision making 2-5 times $(46.7 \%)$ or one time or less $(40.2 \%)$. They also used MEDLINE or other databases to search for practice-relevant literature/research one time or less $(43.1 \%)$ or $2-5$ times $(39.5 \%)$ in an average month.

Regarding the knowledge and the use of practice guidelines, the majority of respondents (69.9-90.1\%) agreed that there were practice guidelines related to their practice. They actively sought and used the guidelines in their clinical practice with the support of their facility. Younger participants who had postgraduate education, were Cis, and were working in urban areas were more likely to read research related to their clinical practice compared with their counterparts (Table 2, Appendix 2).

\section{Perceived Barriers to Using Evidence in Practice}

The three most important perceived barriers as rated by more than $40 \%$ of the respondents were insufficient time, lack of understanding of statistical analysis, and lack of research skills. The perceived barriers rated less respectively (34.8-24.8\%) were poor ability to critically appraise the literature, lack of information resources, inability to apply research findings to individual patients with unique characteristics, lack of collective support among the colleagues in the facility, and lack of generalizability of the literature findings to the patient population. Interestingly, only $14.2 \%$ of the respondents considered lack of interest as their barrier.

Each perceived barrier was influenced by different variables (Table 2, Appendix 2). Participants with fewer years of holding a license, working toward or completed postgraduate education, being a $\mathrm{Cl}$, and who had a greater number of patients to see per day were more likely to report insufficient time to be their barrier. Participants with more years of license holding, only entry-level education, and more numbers of PTs in their workplace were more likely to think that lack of understanding of statistical analysis was their barrier. In addition, participants with only entry-level education and more working hours per weeks were more likely to think that lack of research skills was their barrier (Table 2, Appendix 2). 


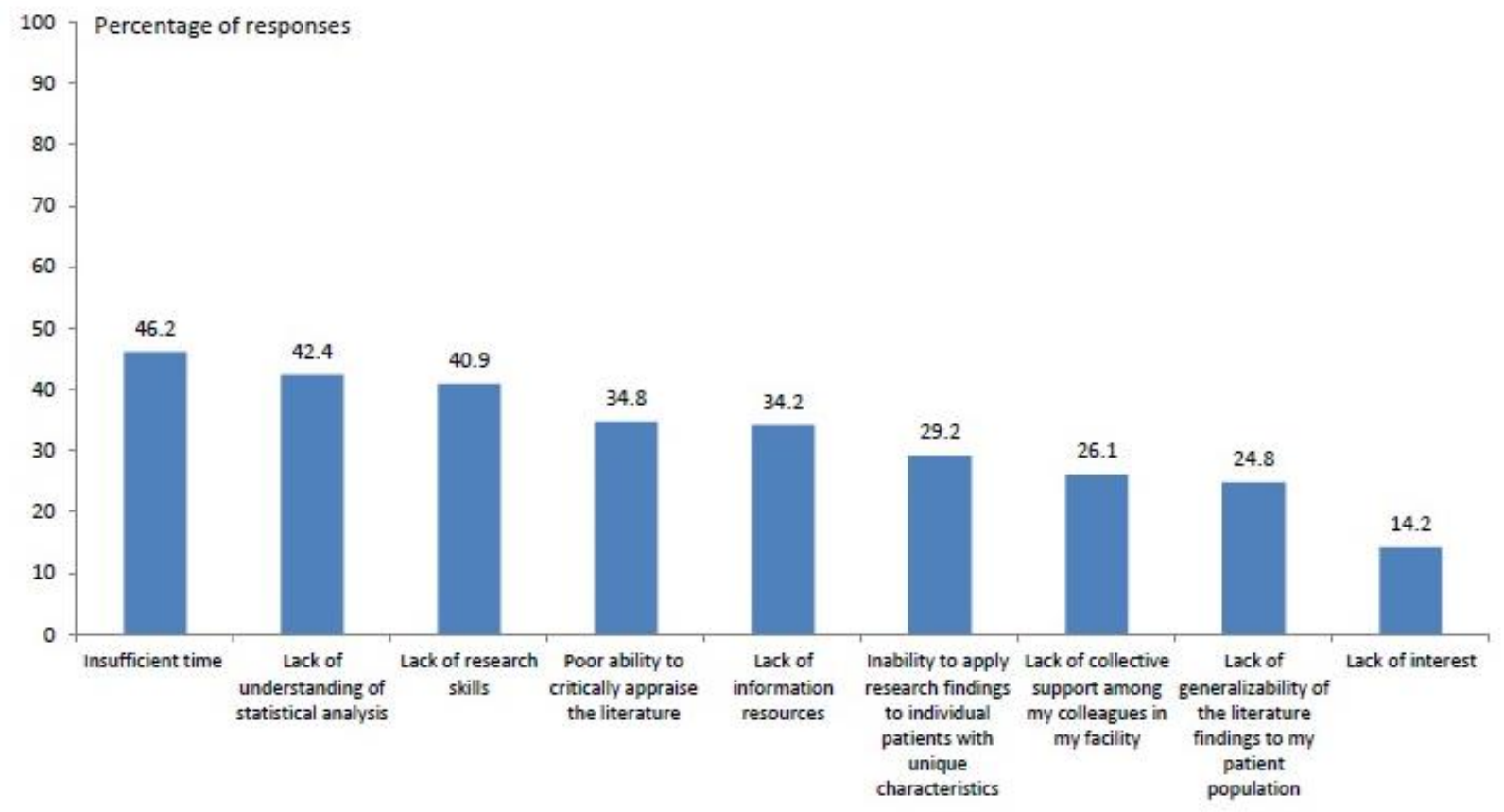

Figure 5. Responses of items regarding the perceived barriers to using evidence in practice

\section{DISCUSSION}

To our knowledge, this study is the first to report information regarding EBP in Thai PTs. Overall, Thai PTs had positive attitudes toward EBP and perceived knowledge sufficient to implement EBP in a clinical setting. However, the frequency of literature searches and critical review was relatively low, and less than half of respondents understood terms related to EBP asked in the questionnaire. The barriers toward EBP included lack of time and limited research and statistical skills. PTs in the younger age group and with education higher than entry-level were more likely to have better attitudes toward and knowledge of EBP as compared to those of their counterparts. These results provided insight into factors contributing to successful implementation of EBP among Thai PTs.

Thai PTs have positive attitudes toward EBP. However, they also express several concerns toward the implementation of EBP in their clinical setting. These findings are similar to those observed in other countries, including the US, Australia, Sweden, Canada, Brazil, Nigeria, Saudi Arabia, and Malaysia. ${ }^{7,8,11,12,14-17,22}$ PTs across the globe viewed EBP and research as a necessary component of clinical practice with an agreement that ranged from 48 to $93 \% .{ }^{6}$ However, more than half of the respondents expressed concerns about the implementation of EBP. These concerns included the lack of evidence to support most PT interventions, limitation of their clinical settings, and an increase in reimbursement rate if EBP were to apply to their settings. A similar range (32 to 61.7\%) of PTs in the US and Malaysia also expressed their concerns regarding the lack of evidence to support their intervention. ${ }^{8,12}$ Additionally, PTs in the US also expressed their concern that EBP might not be practical for actual clinical application. However, these concerns may reflect the doubt, misconception or lack of actual resources supporting EBP uses. ${ }^{6}$

Thai PTs in younger age groups and with an educational level higher than the entry-level bachelor's degree have positive attitudes and beliefs toward EBP. Previously, age and educational level have been identified as factors associated with positive attitudes and beliefs toward EBP.7,12,14 The results of this study are consistent with those findings. Positive beliefs were more likely to be found in younger age groups and more recently licensed PTs in the US and Canada.12,14 The study in Saudi Arabia and Canada found a positive association between the attitude and education level. The higher attitude scores were noted in PTs with higher education level. ${ }^{7,14}$ It is possible that younger PTs who recently graduated from a PT program had taken EBP courses during their academic preparation. Likewise, PTs with an educational level higher than the entry-level had taken courses related to research design and statistics during their advanced study. As a result, these PTs may be familiar with the EBP and have more positive attitudes toward EBP. Collectively, these results reflect the influence of academic preparation on the attitude toward PTs.

The influence of integrating EBP content into an entry-level PT education in Thailand is highlighted in this study. The knowledge of EBP, research, and statistical procedures serve as a necessary foundation for PTs to understand professional literature. ${ }^{16}$

(C) The Internet Journal of Allied Health Sciences and Practice, 2020 
However, the background training of EBP varied largely among PTs practicing in different countries. For example, $29.8 \%$ of participants in Saudi Arabia reported to have formal EBP training and $84.4 \%$ of the Malaysian respondents agreed that they had learned the foundations for EBP during their academic years. 7,8 In this study, the majority of the respondents $(75-91 \%)$ reported that they had sufficient educational background and were confident in performing a literature search, critically appraising the literature, and applying evidence in their practice. Thai PTs in younger groups, recently licensed, and with postgraduate education reported to have sufficient training and more confidence in implementing EBP in clinical practice as compared to their counterparts. The same trend was observed in the study in Malaysia where EBP was introduced in their PT curriculum in the most recent decade. ${ }^{8}$ These results emphasize the needs to provide EBP content and skills to PTs whose EBP content and skills were not part of their academic preparation. This process will allow them to gain the knowledge and skills related to EBP and hopefully result in an improvement in their confidence, attitudes, and implementation of EBP in clinical setting.

To successfully implement EBP in clinical practice, the perceived and actual knowledge about EBP must be consistent within the practitioners. In the present study, although the respondents reported favorable views of knowledge and confidence about EBP, their responses related to the understanding of common EBP terms were not as accordingly high. Less than half of the respondents completely understood all eight statistics and research terms asked, including relative risk, absolute risk, systematic review, odds ratio, meta-analysis, confidence interval, heterogeneity, and publication bias. These findings were similar to those observed among PTs in the US.12 The discrepancy between the confidence in research appraisal and research term recognition may reflect an overestimation of the self-efficacy in EBP as well as the nature of self-reported and anonymous survey. ${ }^{9}$ Awareness and knowledge of EBP terms were associated with age, highest education, work setting, job title, and former EBP training in Saudi Arabia. ${ }^{7}$ In the present study, the respondents who recently graduated and held a postgraduate degree, were more likely to understand all terms related to EBP asked. These results signify the needs to provide and improve EBP education during the academic preparation and as continuing education to improve the implementation of EBP in clinical practice.

Accessibility to and use of the database and literature is one of the required components of EBP. In the present study, the respondents reported they had good online access to the relevant databases at their facility and home. This trend was observed in more recent reports due to the greater availability of internet access and online information. 8,15 However, the majority of Thai PTs (43.1\%) searched for literature less than two times per months as compared to $65 \%$ of PTs in the US in $2003 .{ }^{12}$ At that time, $96 \%$ of PTs in the US reported to have access to paper forms of professional literature compared to $21 \%$ reported in our survey. ${ }^{12}$ Younger age and higher education were also the factors associated with the research access.

The frequency at which PTs search and read research literature partially reflect the implementation of EBP in clinical practice. Although Thai PTs have good access to the internet and database, they read and review literature less often than did PTs in other countries. For example, $66 \%$ and $57.8 \%$ of PTs in the US and Malaysia, respectively, read literature related to their practice two to five times a month, while only $45 \%$ of Thai PTs did.8,12 In the present study, PTs with higher than entry-level educational level were more likely to read literature at a higher frequency of those with the only entry-level degree. The trend of association between higher education and familiarity with the online database as well as self-efficacy to implement EBP has been reported and emphasized the needs for formal training of EBP. $8,11,12,14$

To improve the use of EBP in clinical practice, PTs needs to overcome multiple barriers, including insufficient time. Almost half $(46.2 \%)$ of the respondents indicated that lack of time was the most important barrier to the implementation EBP in their clinical practice. Similar results were reported in Nigeria, Sweden, US, and Malaysia. $1,7,8,12,18$ In the present study, insufficient time for EBP seems to be associated with the long working hours and high numbers of patients seen per day. The process of EBP is known to require a high level of skill as well as time. In our opinion, the lack of time plays a significant role in the relatively low frequency of literature search and appraisal per month, as noted above. Time allocation specific for EBP process as well as knowledge and skill improvement are a great challenge for both practitioners as well as clinic administrators. Given the importance of EBP and its significant impact on the quality of care, the issue of time allocation for EBP must be prioritized such that the implementation of EBP is more applicable and realistic.

The lack of knowledge in research and statistics is also one of the most common barriers to EBP implementation among PTs. ${ }^{11}$ In our study, the lack of research skills, the inability to understand statistics, and a poor ability to critically appraise the literature were the second, third, and fourth frequent reported barriers. These results were in agreement with a relatively high percentage (87.3\%) of respondents identifying their interest to learn or improve their skills necessary to incorporate EBP into practice. Our results are consistent with those studies conducted in other countries. For example, 50\% of PTs in Sweden, $52.8 \%$ in Columbia, $47 \%$ in Malaysia, and $36.4 \%$ in Saudi Arabia also consistently reported the deficiency in EBP knowledge and skills as the important barriers to EBP. $7,8,13,16$ We also believe that by improving the EBP knowledge and skills, the barrier of time constraint may also be reduced. These results emphasize the needs for providing and improving EBP content during academic preparation and continuing education.

(C) The Internet Journal of Allied Health Sciences and Practice, 2020 
The language barrier is one of the most common barriers to EBP. ${ }^{15,16,23} \mathrm{~A}$ survey in Brazilian PTs found that respondents who had better English proficiency reported better knowledge, skills, and attitudes toward EBP. ${ }^{15}$ Although the questionnaire used in this study did not ask about this issue, it is hypothesized that the language barrier may also create a relatively high burden for Thai PTs during critical appraisal of literature because most peer-reviewed research articles are in English. This language barrier is also believed to have a compound and negative impact on the time constraint for implementation of EBP among Thai PTs.

Interestingly, many studies had reported that positive attitudes might not be associated with a high implementation of EBP. $6,7,9,11,15,16$ Hence, many authors suggested that the information related to the actual use of EBP in clinical practice might paint a better picture of the link between the opinions and beliefs. A survey in Brazil indicated that despite favoring EBP, PTs appeared to value experts' opinions in clinical decision-making. ${ }^{15}$ Likewise, PTs in Saudi Arabia relied on personal experiences more than research articles and reviews in decision-making despite their positive attitudes toward EBP. 7 lles reported a discrepancy between the attitudes toward EBP and the actual practice of PTs in Australia. ${ }^{11}$ For examples, there was a high percentage of the respondents reported to have positive attitudes about EBP, but the percentages of respondents who actually performed the searching, appraised and applied as well as understood EBP-related terminology were much lower. ${ }^{11}$ Further studies to explore the explanation of these incongruities are needed.

\section{Limitations}

The major limitation of this study was the relatively low number of respondents. Approximately $4 \%$ of the total number of licensed PT registered in Thailand participated in this study. However, it is expected that approximately $50 \%$ of those registered PTs were currently practicing (personal communication with Physical Therapy Council). Therefore, the number of respondents may represent approximately $8 \%$ of the PTs actively practicing in Thailand. Because of the nature of the online survey, the response rate could not be determined. Nevertheless, the results may be biased toward the PTs who were in younger age groups and had an education level higher than the entry-level bachelor's degree. This limitation may be attributable to the method of an online survey used in this study, which attracts younger and higher educated respondents. Despite the limitations, valuable information related to the attitudes toward, knowledge of, barriers to EBP can be gained from this study

\section{CONCLUSION}

Thai PTs have positive attitudes toward EBP and are interested in acquiring more knowledge and skills specific to EBP. The background education, confidence, and perceived knowledge in EBP are relatively high. However, the actual application and knowledge such as understanding of terminology, searching the literature, and using research in clinical practice do not coincide with the levels of attitude and confidence. Some concerns such as "EBP places an unreasonable demand" or "the increased reimbursement rate if EBP is used" may reflect the misconceptions of EBP. Significant barriers to EBP are lack of time, as well as low levels of confidence with statistics, research, and appraisal skills. Time allocation and formal training in skills required for EBP are recommended to improve the implementation of EBP in clinical practice. However, studies assessing the actual knowledge and skills as well as barriers in steps of EBP implementation will be useful for identifying strategies to promote EBP among Thai PTs successfully.

\section{Acknowledgments}

This study is supported in part by the Physical Therapy Association of Thailand. The authors also would like to acknowledge the presidents of the Physical Therapy Council and the Physical Therapy Association of Thailand for their supports of information of registered practitioners and networks of physical therapists.

\section{REFERENCES}

1. Policy statement: Evidence based practice. WCPT; 2015. https://www.wcpt.org/policy/ps-EBP. Accessed March 1, 2019.

2. Bury T. Evidence based practice: an overview.: WCPT Keynote;2003. https://www.wcpt.org/sites/wcpt.org/files/files/KN-EBPOverview.pdf. Accessed March 1, 2019.

3. Sackett D SS, Richardson W, Rosenberg W, Haynes R. Evidence-Based Medicine: How to Practice and Teach EBM. 2nd ed. Edinburgh: Churchill Livingstone; 2000.

4. Sackett DL, Rosenberg WM, Gray JA, Haynes RB, Richardson WS. Evidence based medicine: what it is and what it isn't. BMJ 1996;312(7023):71-72. PMCID: PMC2349778.

5. da Silva TM, Costa Lda C, Garcia AN, Costa LO. What do physical therapists think about evidence-based practice? A systematic review. Manual Therapy 2015;20(3):388-401. [PMID: 25458142. DOI: 10.1016/j.math.2014.10.009[

6. Scurlock-Evans L, Upton P, Upton D. Evidence-based practice in physiotherapy: a systematic review of barriers, enablers and interventions. Physiotherapy 2014;100(3):208-219. PMID: 24780633 DOl: 10.1016/j.physio.2014.03.001

(C) The Internet Journal of Allied Health Sciences and Practice, 2020 
7. Alshehri MA, Alalawi A, Alhasan H, Stokes E. Physiotherapists' behaviour, attitudes, awareness, knowledge and barriers in relation to evidence-based practice implementation in Saudi Arabia: a cross-sectional study. Int J Evid Based Healthc 2017;15(3):127-141. [PMCID: PMC5592985. DOI: 10.1097/XEB.0000000000000106[

8. Yahui $\mathrm{H}$, Swaminathan, N. Knowledge, attitudes, and barriers towards evidence-based practice among physiotherapists in Malaysia. HKPJ 2017; 37: 10-18. [DOI:10.1016/j.hkpj.2016.12.002[

9. Condon C, McGrane N, Mockler D, Stokes E. Ability of physiotherapists to undertake evidence-based practice steps: a scoping review. Physiotherapy 2016;102(1):10-19. [PMID: 26404896 DOI: 10.1016/j.physio.2015.06.003[

10. Heiwe S, Kajermo KN, Tyni-Lenne R, et al. Evidence-based practice: attitudes, knowledge and behaviour among allied health care professionals. Intl J Qual Health Care 2011;23(2):198-209. [PMID: 21242158 DOI: 10.1093/intghc/mzq083]

11. Iles R, Davidson M. Evidence based practice: a survey of physiotherapists' current practice. Physiother Res Int 2006;11(2):93-103. [PMID: 16808090]

12. Jette DU, Bacon K, Batty C, et al. Evidence-based practice: beliefs, attitudes, knowledge, and behaviors of physical therapists. Phys Ther 2003;83(9):786-805. [PMID: 12940766]

13. Ramirez-Velez R, Bagur-Calafat MC, Correa-Bautista JE, Girabent-Farres M. Barriers against incorporating evidence-based practice in physical therapy in Colombia: current state and factors associated. BMC Med Educ 2015;15:220. [PMCID: PMC4676864 DOI: 10.1186/s12909-015-0502-3]

14. Salbach NM, Jaglal SB, Korner-Bitensky N, Rappolt S, Davis D. Practitioner and organizational barriers to evidence-based practice of physical therapists for people with stroke. Phys Ther 2007;87(10):1284-1303. PMID: 17684088 DOI: 10.2522/ptj.20070040

15. Silva TM, Costa LC, Costa LO. Evidence-Based Practice: a survey regarding behavior, knowledge, skills, resources, opinions and perceived barriers of Brazilian physical therapists from São Paulo state. BJPT 2015;19(4):294-303. [PMCID: PMC4620978 DOI: 10.1590/bjpt-rbf.2014.0102]

16. Nilsagård $\mathrm{Y}$, Lohse $\mathrm{G}$. Evidence-based physiotherapy: A survey of knowledge, behaviour, attitudes and prerequisites. Adv Physiother 2010/12/01 2010;12(4):179-186. [DOI:10.3109/14038196.2010.503812]

17. Akinbo S, Odebiyi, D., Okunola, T., Aderoba, O. Evidence-Based Practice: Knowledge, Attitudes and Beliefs Of Physiotherapists In Nigeria. The Internet Journal of Medical Informatics. 2008;4(2).

18. Grimmer-Somers K, Lekkas P, Nyland L, Young A, Kumar S. Perspectives on research evidence and clinical practice: a survey of Australian physiotherapists. Physiother Res Int 2007;12(3):147-161. JPMID: 17624895 DOI: 10.1002/pri.363]

19. Miravitlles M, Guerrero T, Mayordomo C, Sanchez-Agudo L, Nicolau F, Segu JL. Factors associated with increased risk of exacerbation and hospital admission in a cohort of ambulatory COPD patients: a multiple logistic regression analysis. The EOLO Study Group. Respiration; 2000;67(5):495-501. [PMID: 11070451 DOI: 10.1159/000067462]

20. Bewick V, Cheek L, Ball J. Statistics review 14: Logistic regression. Crit Care 2005;9(1):112-118.

21. Bewick V, Cheek L, Ball J. Statistics review 13: receiver operating characteristic curves. Crit Care 2004;8(6):508-512.

22. Bernhardsson $S$, Johansson $K$, Nilsen $P$, Oberg $B$, Larsson ME. Determinants of guideline use in primary care physical therapy: a cross-sectional survey of attitudes, knowledge, and behavior. Phys Ther 2014;94(3):343-354. [PMID: 24179140 DOI: 10.2522/ptj.20130147]

23. Maher CG, Sherrington C, Elkins M, Herbert RD, Moseley AM. Challenges for evidence-based physical therapy: accessing and interpreting high-quality evidence on therapy. Phys Ther 2004;84(7):644-654. [PMID: 15225083]

(C) The Internet Journal of Allied Health Sciences and Practice, 2020 


\section{Appendix 1: Evidence Based Practice (EBP) Questionnaire}

This part of questionnaire is related to personal attitude towards to use, benefits, and limitations of EBP. For the following questions, please place the check mark $\boldsymbol{x}$ to indicate your answers

1. Application of EBP is necessary in the practice of Physical Therapy.

$\square$ Strongly disagree $\quad \square$ Disagree $\quad \square$ Neutral $\quad \square$ Agree $\square$ strongly agree

2. Literature review and research results (findings) are very beneficial in clinical practice of Physical Therapy.

$\square$ Strongly disagree $\square$ Disagree $\quad \square$ Neutral $\square$ Agree $\square$ strongly agree

3. I should and must increase the use of evidence in my daily practice.

$\square$ Strongly disagree $\quad \square$ Disagree $\quad \square$ Neutral $\quad \square$ Agree $\quad \square$ strongly agree

4. The practice of EBP increases an unnecessary workload on physical therapists.

$\square$ Strongly disagree $\square$ Disagree $\quad \square$ Neutral $\quad \square$ Agree $\square$ strongly agree

5. I am interested in learning or gaining skills necessary to use EBP in clinical practice.

$\square$ Strongly disagree $\quad \square$ Disagree $\quad \square$ Neutral $\quad \square$ Agree $\square$ strongly agree

6. The use of EBP improves the quality of patient care.

$\square$ Strongly disagree $\square$ Disagree $\square$ Neutral $\quad \square$ Agree $\square$ strongly agree

7. EBP does not account for the limitations of my clinical setting.

$\square$ Strongly disagree $\square$ Disagree $\quad \square$ Neutral $\quad \square$ Agree $\square$ strongly agree

8. The cost of Physical Therapy will increase, if I incorporate EBP into my clinical practice.

$\square$ Strongly disagree $\square$ Disagree $\square$ Neutral $\square$ Agree $\square$ strongly agree

9. There is insufficiency in strong evidence to support most of interventions I used with my patients.

$\square$ Strongly disagree $\square$ Disagree $\quad \square$ Neutral $\square$ Agree $\square$ strongly

10. EBP helps me make decisions about patient care.

$\square$ Strongly disagree $\square$ Disagree $\quad \square$ Neutral $\square$ Agree $\square$ strongly

11. EBP does not take into account patient preference.

$\square$ Strongly disagree $\quad \square$ Disagree $\quad \square$ Neutral $\quad \square$ Agree $\quad \square$ strongly

For the following questions, place a mark $₫$ in the appropriate box that indicates your answers for a typical month.

12. Read/review research/literature related to clinical practice

$\square \leq 1$ article $\quad \square 2-5$ articles $\quad \square 6-10$ articles $\quad \square 11-15$ articles $\quad \square>16$ articles

13. Use professional literature and research finding in clinical decision-making process
$\square \leq 1$ time
$\square$ 2-5 times $\quad \square$ 6-10 times
$\square$ 11-15 times
$\square>16$ times

14. Use MEDLINE or other databases to find literature/research related to clinical practice
$\square \leq 1$ time
$\square 2-5$ times
$\square$ 6-10 times
$\square 11-15$ times
$\square>16$ times

Following section inquires about the use and understanding of clinical practice guidelines?

Clinical practice guidelines provide specific standards for care of patients with specific disease and are developed through a process that has good consensus with the highest scientific evidence and expert opinions. For the following questions, place a $\triangle$ mark in the appropriate box that indicates your answer.

15. Practice guidelines are available in the topics related to my practice
$\square$ Yes
$\square$ No $\quad \square$ Do not know

16. I actively find practice guidelines that are related to (or pertaining) to area of my practice.

$\square$ Strongly disagree $\quad \square$ Disagree $\quad \square$ Neutral $\quad \square$ Agree $\quad \square$ strongly agree

17. I use practice guidelines in my clinical practice.

$\square$ Strongly disagree $\quad \square$ Disagree $\quad \square$ Neutral $\quad \square$ Agree $\quad \square$ strongly agree

18. I know that practice guidelines are available online.
$\square$ Yes
$\square$ No

19. I have access to practice guidelines online.
$\square$ Yes
$\square$ No

20. I am able to (can) use (integrate, incorporate) patient preference with practice guidelines.

$\square$ Yes $\square$ No

The following section inquiries about available resources to access information and personal skills in using those resources.

For the following questions, place a $\boldsymbol{\otimes}$ mark in the appropriate box that indicates your answer. In questions related to "work place (facility?)", please consider the clinical setting in which you do the majority of clinical practice.

21. I access new (current) research through professional journals in the paper form.
$\square$ Yes
$\square$ No

(c) The Internet Journal of Allied Health Sciences and Practice, 2020 
22. I can (am able to) access to databases and internet at my work place (facility).
$\square$ Yes
$\square$ No $\quad \square$ Do not know

23. I can (am able to) access to related databases and internet at home and locations other than my workplace. $\square$ Yes $\square$ No

24. My facility supports the use of current research in clinical practice.

$\square$ Strongly disagree $\square$ Disagree $\square$ Neutral $\square$ Agree $\square$ strongly agree

25. I learned basic foundation of EBP as part of knowledge before I started working here.

$\square$ Strongly disagree $\square$ Disagree $\square$ Neutral $\square$ Agree $\square$ strongly agree

26. I have received formal training in search strategies for finding research related to my clinical practice.

$\square$ Strongly disagree $\square$ Disagree $\square$ Neutral $\square$ Agree $\square$ strongly agree

27. I am familiar with the medical search engines (e.g., MEDLINE, CINAHL).

$\square$ Strongly disagree $\square$ Disagree $\square$ Neutral $\square$ Agree $\square$ strongly agree

28. I have receiving formal training in appraisal of research literature as part of formal education prior to working.

$\square$ Strongly disagree $\square$ Disagree $\square$ Neutral $\square$ Agree $\square$ strongly agree

29. I am confident that I am able to (can) critically review professional literature.

$\square$ Strongly disagree $\square$ Disagree $\square$ Neutral $\square$ Agree $\square$ strongly agree

30. I am confident that I can search for research to answer my clinical questions.

$\square$ Strongly disagree $\square$ Disagree $\square$ Neutral $\square$ Agree $\square$ strongly agree

For the following questions, please make a $\mathbf{x}$ in the box

31. My understanding about these words:
a) Relative risk
b) Absolute risk
c) Systematic review
d) Odds ratio
e) Meta-analysis
f) Confidence interval
g) Heterogeneity
h) Publication bias

Understand completely

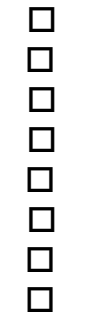

Somewhat understand

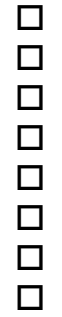

Do not understand

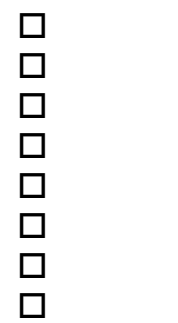

For the following questions, rank top 3 choices

32. Rank top 3 barriers of using EBP in your clinical practice

$\square$ Insufficient time

$\square \quad$ Lack of database

$\square \quad$ Lack of research skills

$\square$ Insufficient (poor) ability in critical appraisal of literature

$\square$ Lack of use of literature/research findings in patient population

$\square \quad$ Inability to apply research findings to individual patients with specific characteristics

$\square$ Lack of understanding of statistical analysis

$\square \quad$ Lack of support from my colleagues at my work place

$\square \quad$ Lack of interestFollwing questions inquires about your personal information

33. What is your sex?

$\square$ Male $\square$ Female

34. What is your age group?
$\square 20-29$ years
30-39 years
40-49 years
more than 50 years

35. Do you currently hold a professional license?
$\square$ Yes
$\square$ No

36. How long have you been licensed?
$\square$ Less than 5 years $\square 5$ - 10 years

37. What is your highest level of education?
$\square$ Bachelor Degree
$\square$ Master Degree
$\square$ Postgraduated diploma (Specialized fields)
$\square$ Doctoral Degree

38. If you have not had a post graduate degree, do you intend to pursue one?
$\square$ Yes
$\square$ No
$\square$ Not known

39. Do you regularly attend a continuing education course ( $(\geq 1$ time/year)?
$\square$ Yes
$\square$ No

(C) The Internet Journal of Allied Health Sciences and Practice, 2020 
40. Are you a member of PT professional organization (for example, Thai PT association)?

$$
\square \text { Yes } \square \text { No }
$$

41. Are you a clinical instructor of PT student/interns?

$$
\square \text { Yes } \square \text { No }
$$

42. On average, how many hours per week do you work?
$\square$ Less than 20 hours
$\square$ 20-30 hours
$\square$ 31-40 hours $\square$ More than 40 hours

43. On average, how many patients per day do you see?
$\square$ Less than 5
$\square$ 5-10
$\square$ 11-15 $\square$ More than 15

44. How many full-time PTs are there at your facility?
$\square$ Less than 5
$\square$ 5-10
$\square$ 11-15 $\square$ More than 15

45. Please provide ratio of activities you do during a typical month

Patient care $\quad \%$ of time
Research $— \%$ of time
Teaching $\quad \%$ of time

46. Which one best describing the location of your practice?
$\square$ Rural
$\square$ Urban
$\square$ Suburban

47. Which one best describes the facility of your practice?

$\square$ University hospital $\quad \square$ Specialized hospital $\quad \square$ Center Hospital $\quad \square$ Provincial hospital

$\square$ Community Hospital $\square$ Primary Care Unit $\square$ Rehabilitation /Intermediate care center

$\square$ Home visit/Home care service $\square$ Physical Therapy Clinic (Private practice)

$\square$ Special education school $\square$ Other Please identify

48. Types of patients in your major practice

$\square$ Orthopedics $\square$ Neurological $\square$ Cardiovascular/Pulmonary $\quad \square$ Others

$\square$ Children (< 18 years) $\quad \square$ Adults (19-64 years) $\quad \square$ older adults ( $\geq 65$ years) 
APPENDIX 2.: Regression Models of the Major Items of the Five Themes

\begin{tabular}{|c|c|c|c|c|c|}
\hline & Factor & Level & $\begin{array}{l}\text { Odds ratio } \\
(95 \% \mathrm{Cl})\end{array}$ & $\begin{array}{l}\text { Model R2 } \\
\text { (p-value) }\end{array}$ & $\begin{array}{c}\text { AUROC }(95 \% \mathrm{Cl}) \\
\text { (p-value) }\end{array}$ \\
\hline \multirow{15}{*}{$\begin{array}{l}\text { Attitude and concerns: } \\
\text { Application of EBP is } \\
\text { necessary in the practice } \\
\text { of physical therapy }\end{array}$} & Age & $20-29 y$ & $2.2(1.1-4.6)$ & 0.084 & $0.68(0.62-0.75)$ \\
\hline & & $30-39 y$ & $3.0(1.4-6.6)$ & $(<0.001)$ & $(<0.001)$ \\
\hline & & $>40 y$ & reference & & \\
\hline & Education & Postgraduate & $1.8(0.9-3.7)$ & & \\
\hline & & Bachelor & reference & & \\
\hline & $\mathrm{Cl}$ & Yes & $1.8(1.0-3.4)$ & & \\
\hline & & No & reference & & \\
\hline & Patients & $<5$ & $4.6(1.2-17.3)$ & & \\
\hline & per day & $5-10$ & $1.4(0.7-2.8)$ & & \\
\hline & & $11-15$ & $1.1(0.5-2.3)$ & & \\
\hline & & $>15$ & reference & & \\
\hline & PTs in & $<5$ & $1.6(0.8-3.5)$ & & \\
\hline & workplace & $5-10$ & $1.0(0.4-2.0)$ & & \\
\hline & & $11-15$ & $4.5(1.0-21.4)$ & & \\
\hline & & $>15$ & reference & & \\
\hline \multirow{7}{*}{$\begin{array}{l}\text { Perceived knowledge } \\
\text { and skill: I learned the } \\
\text { foundations for EBP as } \\
\text { part of my academic } \\
\text { preparation }\end{array}$} & Age & $20-29 y$ & $3.6(1.5-8.7)$ & 0.133 & $0.68(0.64-0.72)$ \\
\hline & & $30-39 y$ & $2.4(1.1-5.2)$ & $(<0.001)$ & $(<0.001)$ \\
\hline & & $>40 \mathrm{y}$ & reference & & \\
\hline & Year & $<5 y$ & $2.3(1.0-5.6)$ & & \\
\hline & holding & $5-10 y$ & $1.1(0.5-2.5)$ & & \\
\hline & license & $11-15 y$ & $1.1(0.5-2.4)$ & & \\
\hline & & $>15 y$ & reference & & \\
\hline \multirow{11}{*}{$\begin{array}{l}\text { Understanding of the } \\
\text { terms "Meta-analysis" }\end{array}$} & Gender & Male & $1.5(1.0-2.2)$ & 0.172 & $0.71(0.67-0.75)$ \\
\hline & & Female & reference & $(<0.001)$ & $(<0.001)$ \\
\hline & Age & $20-29 y$ & $4.8(2.6-8.9)$ & & \\
\hline & & $30-39 y$ & $2.1(1.1-3.9)$ & & \\
\hline & & $>40 y$ & reference & & \\
\hline & Education & Post grad & $4.2(2.8-6.3)$ & & \\
\hline & & Bsc & reference & & \\
\hline & Working & $<20 h$ & $2.6(1.3-5.2)$ & & \\
\hline & hours per & $20-30 h$ & $1.2(0.7-2.2)$ & & \\
\hline & week & $31-40 \mathrm{~h}$ & $0.8(0.5-1.2)$ & & \\
\hline & & $>40 \mathrm{~h}$ & reference & & \\
\hline \multirow{9}{*}{$\begin{array}{l}\text { Access to and } \\
\text { availability of } \\
\text { information: } \\
\text { I have the ability to access } \\
\text { relevant databases and } \\
\text { the Internet at my facility }\end{array}$} & $\mathrm{Cl}$ & Yes & $0.4(0.3-0.6)$ & 0.068 & $0.63(0.57-0.68)$ \\
\hline & & No & reference & $(<0.001)$ & $(<0.001)$ \\
\hline & Patients & $<5$ & $0.5(0.3-1.0)$ & & \\
\hline & per day & $5-10$ & $0.4(0.2-0.7)$ & & \\
\hline & & $11-15$ & $0.7(0.4-1.2)$ & & \\
\hline & & $>15$ & reference & & \\
\hline & Area of & Rural & $0.6(0.3-1.2)$ & & \\
\hline & workplace & Urban & $1.3(0.8-2.2)$ & & \\
\hline & & Suburban & reference & & \\
\hline
\end{tabular}




\begin{tabular}{|c|c|c|c|c|c|}
\hline \multirow{4}{*}{$\begin{array}{l}\text { Attention to literature } \\
\text { relevant to practice: } \\
\text { I read/review } \\
\text { research/literature related to } \\
\text { my clinical practice }\end{array}$} & Age & $\begin{array}{l}20-29 y \\
30-39 y \\
>40 y\end{array}$ & $\begin{array}{c}3.2(2.0-5.4) \\
2.0(1.2-3.3) \\
\text { reference }\end{array}$ & $\begin{array}{c}0.097 \\
(<0.001)\end{array}$ & $\begin{array}{c}0.65(0.61-0.69) \\
(<0.001)\end{array}$ \\
\hline & Education & $\begin{array}{l}\text { Postgraduate } \\
\text { Bachelor }\end{array}$ & $\begin{array}{l}2.6(1.8-3.9) \\
\text { reference }\end{array}$ & & \\
\hline & $\mathrm{Cl}$ & $\begin{array}{l}\text { Yes } \\
\text { No }\end{array}$ & $\begin{array}{l}1.5(1.1-2.1) \\
\text { reference }\end{array}$ & & \\
\hline & $\begin{array}{l}\text { Area of } \\
\text { workplace }\end{array}$ & $\begin{array}{l}\text { Rural } \\
\text { Urban } \\
\text { Suburban }\end{array}$ & $\begin{array}{c}1.2(0.7-1.9) \\
1.9(1.2-2.9) \\
\text { reference }\end{array}$ & & \\
\hline \multirow[t]{4}{*}{ Barrier: Insufficient time } & $\begin{array}{l}\text { Year } \\
\text { holding } \\
\text { license }\end{array}$ & $\begin{array}{l}>5 y \\
5-10 y \\
11-15 y \\
>15 y\end{array}$ & $\begin{array}{c}1.9(1.1-3.2) \\
1.4(0.9-2.3) \\
0.8(0.4-1.3) \\
\text { reference }\end{array}$ & $\begin{array}{c}0.091 \\
(<0.001)\end{array}$ & $\begin{array}{c}0.65(0.61-0.69) \\
(<0.001)\end{array}$ \\
\hline & Education & $\begin{array}{l}\text { Postgraduate } \\
\text { Bachelor }\end{array}$ & $\begin{array}{l}2.5(1.7-3.7) \\
\text { reference }\end{array}$ & & \\
\hline & $\mathrm{Cl}$ & $\begin{array}{l}\text { Yes } \\
\text { No }\end{array}$ & $\begin{array}{l}1.4(1.0-2.0) \\
\text { reference }\end{array}$ & & \\
\hline & $\begin{array}{l}\text { Patients } \\
\text { per day }\end{array}$ & $\begin{array}{l}<5 \\
5-10 \\
11-15 \\
>15 \\
\end{array}$ & $\begin{array}{c}0.4(0.2-0.7) \\
0.4(0.3-0.7) \\
0.6(0.4-1.0) \\
\text { reference }\end{array}$ & & \\
\hline \multirow[t]{3}{*}{$\begin{array}{l}\text { Lack of understanding of } \\
\text { statistical analysis }\end{array}$} & $\begin{array}{l}\text { Year } \\
\text { holding } \\
\text { license }\end{array}$ & $\begin{array}{l}>5 y \\
5-10 y \\
11-15 y \\
>15 y\end{array}$ & $\begin{array}{c}0.8(0.5-1.3) \\
1.3(0.8-2.1) \\
1.6(1.0-2.8) \\
\text { reference }\end{array}$ & $\begin{array}{c}0.049 \\
(<0.001)\end{array}$ & $\begin{array}{c}0.61(0.57-0.65) \\
(<0.001)\end{array}$ \\
\hline & Education & $\begin{array}{l}\text { Postgraduate } \\
\text { Bachelor }\end{array}$ & $\begin{array}{l}0.7(0.5-1.0) \\
\text { reference }\end{array}$ & & \\
\hline & $\begin{array}{l}\text { PTs in } \\
\text { workplace }\end{array}$ & $\begin{array}{l}<5 \\
5-10 \\
11-15 \\
>15 \\
\end{array}$ & $\begin{array}{c}0.6(0.4-0.9) \\
1.0(0.6-1.6) \\
0.7(0.4-1.3) \\
\text { reference }\end{array}$ & & \\
\hline \multirow[t]{3}{*}{ Lack of research skills } & $\begin{array}{l}\text { Year } \\
\text { holding } \\
\text { license }\end{array}$ & $\begin{array}{l}>5 y \\
5-10 y \\
11-15 y \\
>15 y\end{array}$ & $\begin{array}{c}0.3(0.2-0.4) \\
0.5(0.3-0.7) \\
0.6(0.3-1.0) \\
\text { reference }\end{array}$ & $\begin{array}{c}0.110 \\
(<0.001)\end{array}$ & $\begin{array}{c}0.67(0.62-0.71) \\
(<0.001)\end{array}$ \\
\hline & Education & $\begin{array}{l}\text { Postgraduate } \\
\text { Bachelor }\end{array}$ & $\begin{array}{l}0.4(0.3-0.6) \\
\text { reference }\end{array}$ & & \\
\hline & $\begin{array}{l}\text { Working } \\
\text { hours per } \\
\text { week }\end{array}$ & $\begin{array}{l}<20 \mathrm{~h} \\
20-30 \mathrm{~h} \\
31-40 \mathrm{~h} \\
>40 \mathrm{~h}\end{array}$ & $\begin{array}{c}0.5(0.2-1.1) \\
0.5(0.2-0.9) \\
1.1(0.8-1.5) \\
\text { reference }\end{array}$ & & \\
\hline
\end{tabular}

Note: EBP=Evidence-based practice; $\mathrm{Cl=Clinical}$ instructor; PTs=Physical therapists; AUROC=Area under the receiver operating characteristic. 